Malwina SIEWIER

Uniwersytet Humanistyczno-Przyrodniczy

im. Jana Dlugosza w Czestochowie ${ }^{1}$

Wydzial Nauk Spolecznych, Katedra Nauk o Bezpieczeństwie malwina.siewier@gmail.com

ORCID 0000-0001-6734-0745

https://doi.org/10.34739/dsd.2020.02.15

\title{
METODY DZIALALNOŚCI POLICJI POLITYCZNEJ W DRUGIEJ RZECZYPOSPOLITEJ. WYBRANE PROBLEMY
}

\begin{abstract}
ABSTRAKT: W artykule przedstawiono wybrane problemy działalności polskiej policji politycznej w latach 1919-1939. Omówiono m.in. zmiany organizacyjne oraz model pracy operacyjnej tej formacji. Przedstawiono metody działalności, zwłaszcza wywiad konfidencjonalny, inwigilację i obserwację. Wiele uwagi poświęcono kwestiom współpracy z informatorami i konfidentami. Omówiono obowiązujące zasady w tym względzie. Zwrócono uwagę na dobórwspółpracowników. Wyeksponowano problem oceny wiarygodności przekazywanych przez nich materiałów. Omówiono podstawowe zadania policji politycznej, uwzględniając istniejące zagrożenia bezpieczeństwa. Zwrócono uwagę, że ich zakres zmieniał się zależnie od wytycznych władz państwowych.
\end{abstract}

SŁOWA KLuCzowe: Policja Państwowa, policja polityczna, bezpieczeństwo w latach 1919-1939, zwalczanie zagrożeń, metody pracy operacyjnej policji

\section{METHODS OF ACTIVITIES OF POLITICAL POLICE IN THE SECOND REPUBLIC OF POLAND. SELECTED PROBLEMS}

ABSTRACT: The article presents selected problems of the activities of the Polish political police in 1919-1939. The author disscused organizational changes and the operational work model of this formation and presented methods of activity, especially confidential intelligence, surveillance and observation. Much attention was devoted to issues of cooperation with informants and informers. Applicable principles in this respect were discussed. Attention was paid to the selection of secret colleagues. The problem of assessing the credibility of the materials they provide was highlighted. The basic tasks of the political police were discussed, taking into account existing security threats. It was noted that their the scope of tasks changed depending on the guidelines of state authorities.

KEYWORDS: State Police, political police, security in 1919-1939, combating threats, methods of police operational work

${ }^{1}$ Jan Dlugosz University in Czestochowa; Poland 


\section{WPROWADZENIE}

Policja Państwowa (PP), powołana w 1919 r., była formacją odpowiedzialną za ochronę bezpieczeństwa, spokoju i porządku publicznego w Drugiej Rzeczypospolitej. Zorganizowano ją odpowiednio do podziału administracyjnego $\mathrm{kraju}^{2}$. Wyjątek stanowiło autonomiczne województwo śląskie, na którego obszarze działalność w tym zakresie od 1922 r. prowadziła Policja Województwa Śląskiego (PWŚ) ${ }^{3}$. W latach 1919-1939 kilkukrotnie przeprowadzano reorganizację struktur $\mathrm{PP}^{4}$. Od samego początku istnienia tego wyspecjalizowanego organu bezpieczeństwa obok policji mundurowej funkcjonowała służba śledcza. Pierwsza $\mathrm{z}$ nich wykonywała przede wszystkim zadania o charakterze prewencyjnym i administracyjnoporządkowym. Służba śledcza realizowała zadania operacyjno-rozpoznawcze, a w zakresie jej zainteresowań były sprawy polityczne, kryminalne i gospodarcze 5 . W okresie międzywojennym przeprowadzono kilka zmian organizacyjnych policji politycznej. Zadania o charakterze politycznym realizowano w ramach następujących jednostek: Defensywa Polityczna (tzw. „Defa”), Wydział IV-D, Służba Informacyjna, Policja Polityczna, Służba Śledcza. Niezależnie od przeprowadzanych reform specyfika ich działania i główne cele zasadniczo się nie zmieniały, co pozwala przyjąć określenie ,policja polityczna” dla całego okresu działalności tej formacjí.

Celem artykułu jest przedstawienie niektórych aspektów działalności polskiej policji politycznej w latach 1919-1939. Zostaną w nim wyeksponowane metody pracy wykorzystywane w służbie śledczej, z uwzględnieniem istniejących uwarunkowań. Pion ten realizował zadania w zakresie bezpieczeństwa II Rzeczpospolitej, co jest problemem badawczym. Nurtujące zagadnienia opracowano w oparciu o metodę analizy źródeł archiwalnych oraz krytyczną analizą literatury przedmiotu. Bazę źródłową artykułu stanowią materiały archiwalne. Wykorzystano również opracowania naukowe poświęcone niektórym aspektom badanej problematyki.

\section{UTWORZENIE DEFENSYWY POLITYCZNEJ}

Ze względu na brak materiałów źródłowych trudno jednoznacznie określić początek funkcjonowania policji politycznej. $Z$ dostępnych dokumentów wynika, że pion ten zaczęto

\footnotetext{
${ }^{2}$ Archiwum Państwowe w Katowicach, Policja Województwa Śląskiego, sygn. 109, Instrukcja służbowa o Policji Państwowej i postępowaniu w służbie, brak roku (b.r.), s. 7.

${ }^{3}$ Policja Województwa Śląskiego (PWŚ) była wzorowanym na Policji Państwowej (PP) organem, ale od niej odrębnym. Między obu formacjami istniało wiele podobieństw. Wielokrotnie przepisy wydawane przez Komendę Główną Policji Państwowej, również w zakresie organizacji służby śledczej, były przejmowane przez Główną Komendę Policji Województwa Śląskiego i wykorzystywane na użytek śląskiego korpusu. Zresztą podjęto wiele prób połączenia obu formacji. Zwolennikiem takiego rozwiązania był główny komendant insp. Leon Wróblewski. Podobne starania podjęli jego następcy, zwłaszcza insp. Józef Żółtaszek. Do połączenia ostatecznie nie doszło ze względu na autonomię województwa śląskiego i odrębne ustawodawstwo. J. Mikitin, Szkolnictwo policyjne $w$ województwie ślaskim $w$ okresie międzywojennym, rozprawa doktorska, Uniwersytet Śląski, Wydział Nauk Społecznych, Instytut Historii, Katowice 2007, s. 35-44.

${ }^{4}$ A. Misiuk, Policja Państwowa 1919-1939: powstanie, organizacja, kierunki działania, Warszawa 1996, s. 58-59.

${ }^{5}$ B. Sprengel, Policja Państwowa a organy władzy publicznej w polityce ochrony bezpieczeństwa wewnętrznego w Polsce w latach 1918-1939, Torun 2011, s. 36-37.

${ }^{6}$ K. Halicki, Policja Polityczna w województwie pomorskim w latach 1920-1939, Łódź 2015, s. 16.
} 
organizować zaraz po utworzeniu PP (choć możliwe, że już wcześniej istniały komórki policyjne, realizujące sprawy polityczne). Jej działalność starano się utrzymywać w tajemnicy, co z perspektywy bezpieczeństwa państwa nie było dobrym rozwiązaniem. Ochrona państwa przed zagrożeniami politycznymi była niezwykle istotna, utajnienie istnienia takiej służby stwarzało jednak niebezpieczeństwo jej działania poza kontrolą władzy ${ }^{7}$. W okólniku Komendy Głównej PP z 16 października 1919 r. stwierdzono, że ,sprawy natury politycznej należeć będą do kompetencji Inspektoratu Defensywy Politycznej. Wszystkie sprawy kierowane do Wydziału V i IC należy kierować do KG PP do inspektoratu DP”8. 23 marca 1921 r. minister spraw wojskowych, gen. Kazimierz Sosnkowski, określił zadania dla służb wywiadu i kontrwywiadu w czasie pokoju. Część kompetencji w zakresie służby informacyjno-defensywnej przekazano policji i administracji państwowej. PP przypisano wiele zadań związanych z kontrwywiadowczą ochroną państwa. Rok później Ministerstwo Spraw Wewnętrznych (MSW) wydało tajny okólnik nr 12, określający zasady współpracy Oddziału II Sztabu Generalnego, od 1928 r. Głównego (SG) Wojska Polskiego (WP) z Policją Państwową. Zgodnie z wytycznymi placówki Oddziału II miały realizować zadania związane z obronnością państwa. Defensywa Polityczna miała odpowiadać za zwalczanie działalności antypaństwowej w kraju?

\section{WYDZIAL IV-D}

W 1922 r. w strukturach organizacyjnych PP utworzono dział służby śledczej oznaczony kryptonimem IV-D. Jego głównym zadaniem było wykrywanie i zwalczanie przestępstw o charakterze politycznym, wymierzonych przeciwko bezpieczeństwu państwa, zakłócających jego wewnętrzny spokój i porządek. Ramy działalności policji politycznej określono w Instrukcji o sposobach prowadzenia stużby śledczej w zakresie resortu Wydziału IV-D przez powiatowe komendy PP. Czytamy w niej m.in.: „Dział śledczy IV-D, stanowiący jeden ze specjalnych działów Policji Państwowej, jest powołany, obok policji mundurowej oraz kryminalnej, do ujawniania czynów karygodnych, skierowanych przeciwko Państwu jako takiemu i przeciw wewnętrznemu porządkowi w Państwie oraz zapobiegania tym czynom - w szczególności zaś do zapobiegania rozruchom wewnętrznym, zagrażającym ustrojowi i bezpieczeństwu Państwa, ujawniania knowań antypaństwowych i nielegalnych objawów życia politycznego"10.

Wydział IV-D był centralą inwigilacyjno-polityczną. Przesyłano do niej wszystkie sprawy dotyczące osób cywilnych. Czasem ich właściwe załatwienie było trudne, m.in. ze względu na spory kompetencyjne z organami wojskowymi oraz konflikty we współpracy

\footnotetext{
${ }^{7}$ B. Sprengel, Policja Państwowa..., s. 36.

${ }^{8}$ A. Misiuk, System stużb specjalnych w II RP, [w:] Kontrwywiad II RP (1914) 1918-1945 (1948), t. II, red. Z. Nawrocki, Warszawa 2014, s. 13.

${ }^{9}$ Ibidem, s. 15.

10 E. Długajczyk, Agendy polityczno-śledcze Policji Województwa Śląskiego w latach 1922-1939, „Szkice Archiwalno-Historyczne", 2010, nr 6, s. 40.
} 
z administracją państwową. Nie bez znaczenia dla efektywności pracy policji politycznej były liczne przekształcenia organizacyjne, które prowadziły do zmian w zakresie jej kompetencji ${ }^{11}$.

W tym czasie działalność Wydziału IV-D PP została zdecentralizowana. We wszystkich okręgowych komendach korpusu policji powstały agentury IV-D, nazywane ekspozyturami Wydziału IV-D. Odpowiadały one przede wszystkim za zbieranie materiałów dotyczących stanu bezpieczeństwa w okręgu, a także materiałów zbiorowej inwigilacji, zbieranie materiałów indywidualnej inwigilacji, przydzielanie spraw funkcjonariuszom, instruowanie w zakresie rozpoznania wywiadowczego oraz prowadzenia dochodzeń politycznych, instruowanie i kontrolę powiatowych komend w zakresie funkcjonowania Wydziału IV-D oraz prowadzenie szkoleń dla wywiadowców, prowadzenie ważniejszych dochodzeń policyjnych lub obejmujących kilka powiatów, poprzez oddelegowanie wyższego funkcjonariusza. Większość zadań związanych ze zwalczaniem przestępczości politycznej, wykonywały agentury IV-D w powiatach przy pomocy jawnych organów bezpieczeństwa, czyli komisariatów i posterunków policji. Zasadę tę stosowano w całym kraju ${ }^{12}$.

Kadrę agentur IV-D tworzyli specjalnie wyszkoleni funkcjonariusze. Agentury powoływano przede wszystkim w miejscowościach, w których znajdowały się większe centra przemysłowe i handlowe, duże skupiska mniejszości narodowych oraz powiatach położonych w obszarze przygranicznym. Kierownikami agentur IV-D byli referenci spraw śledczych powiatowych komend. Na polecenie starostów czy powiatowych komendantów zajmowali się referowaniem spraw $\mathrm{z}$ zakresu prowadzonego działu oraz odpowiadali za prowadzenie czynności związanych $\mathrm{z}$ wywiadem politycznym. Niektóre $\mathrm{z}$ powiatowych komend nie posiadały agentur. Wszystkie sprawy prowadzili wówczas komendanci jednostek lub - po uzyskaniu zgody komendanta głównego PP - odpowiednio wyszkoleni funkcjonariusze ${ }^{13}$.

\section{SŁUŻBA INFORMACYJNA}

26 kwietnia 1923 r. przeprowadzono reorganizację służby śledczej PP. Zlikwidowano Wydział IV-D KG PP i utworzono Służbę Informacyjną. Przepisy wykonawcze określały, że ,[...] funkcjonariusze służby informacyjnej są funkcjonariuszami policyjnymi służby śledczej, pozostającymi na etacie i budżecie Policji Państwowej, odkomenderowanymi do odnośnych władz administracyjnych do dyspozycji tych ostatnich"14. W kraju utworzono Wojewódzkie Oddziały Informacyjne. Agentury IV-D przekształcono na agentury informacyjne, które weszły w skład władz administracyjnych I instancji. Były one organami wykonawczymi w sprawach

\footnotetext{
${ }^{11}$ B. Mącior-Majka, Policja polityczna: zadania i ich realizacja w latach 1919-1926, [w:] Kontrwywiad II RP (1914) 1918-1945 (1948), t. II, red. Z. Nawrocki, Warszawa 2014, s. 45.

${ }^{12}$ APK, PWŚ, sygn. 24, Pismo GK PP w Warszawie, dot. zmian w organizacji Ekspozytur i Agentur IV-D PP, z 17.10.1922r., k. 32-33.

${ }^{13}$ APK, PWŚ, sygn. 24, Dokument KG PP, Instrukcja o sposobie prowadzenia służby śledczej w zakresie resortu Wydziału IV-D przez Kom. Pow. PP, b.r., k. 21-22.

${ }^{14}$ APK, PWŚ, sygn. 24, Przepisy wykonawcze do Okólnika MSW nr 10 z 26 kwietnia 1923r., z 27.07.1923r., k. 34-35.
} 
przestępczości antypaństwowej. Ich personel pod względem administracyjnym, gospodarczym i wyszkolenia podlegał KG PP, służbowo natomiast władzom administracji państwowej ${ }^{15}$.

Służba informacyjna miała zwalczać przestępczość polityczną. Prowadziła ona stosowne dochodzenia zwane śledczymi. Funkcjonariusze policji mundurowej byli zobowiązani do bezzwłocznego zawiadomienia pracowników agentury informacyjnej o popełnionych przestępstwach. Do chwili jej przybycia na miejsce zdarzenia funkcjonariusze policji mundurowej zabezpieczali ślady i materiały dowodowe oraz ustalali personalia świadków. W sytuacji uzasadnionego podejrzenia, że dana osoba podejmie próby zatarcia śladów bądź zniszczenia materiałów dowodowych, zatrzymywano ją do czasu przybycia pracowników służby informacyjnej, którzy podejmowali dalsze czynności dochodzeniowo-śledcze ${ }^{16}$.

Model działalności służby informacyjnej w ramach administracji państwowej nie był w pełni sprawny. Organy policyjne nie mogły prowadzić systematycznego wywiadu politycznego, co doprowadziło do ograniczonego rozpoznania sytuacji politycznej na danym obszarze. Współpraca między policją mundurową a służbą informacyjną nie była efektywna ${ }^{17}$.

\section{Policja POLityczna}

Kolejną reorganizację służby śledczej przeprowadzono reskryptem z 14 sierpnia $1924 \mathrm{r}$. Przepisy dotyczące powołania Policji Politycznej zaczęły obowiązywać od 1 września 1924 r. Wojewódzkie Oddziały Informacyjne przemianowano na Urzędy Policji Politycznej. Agentury informacyjne we wszystkich powiatowych komendach przekształcono natomiast w ekspozytury Policji Politycznej, będące integralną częścią władz administracyjnych ${ }^{18}$. Reorganizacja służby śledczej z 1 września 1924 r. była de facto powrotem do stanu poprzedniego. Poza nazwą zakres jej działalności w zasadzie nie uległ zmianie.

Policja Polityczna - jako służba specjalistyczna - od początku swojego istnienia była traktowana w szczególny sposób. Kandydatom do pracy stawiano wysokie wymagania. Funkcjonariusze na tle całego korpusu policyjnego mieli wyróżniać się pod względem intelektualnym, moralnym i zawodowym. Nie zawsze jednak spełniali te kryteria. Skierowanie do służby w Policji Politycznej było swego rodzaju awansem zawodowym ${ }^{19}$. Kandydaci przechodzili odpowiednie kursy i szkolenia. W ramach wdrożonego w 1924 r. Programu 12miesięcznego szkolenia funkcjonariuszy Policji Politycznej omawiano działania pionu śledczego, w którym wyszczególniono następujące zagadnienia: cele i zadania policji w służbie śledczej; cechy, jakimi powinien odznaczać się funkcjonariusz; znajomość lokalnych stosunków jako jedna z podstawowych umiejętności, którą powinien posiadać funkcjonariusz

\footnotetext{
15 APK, PWŚ, sygn. 25, Sprawozdanie z lustracji Głównej Komendy Policji Województwa Śląskiego z 13.02. 1930r., k. 182.

${ }^{16}$ APK, PWŚ, sygn. 12, Rozkaz oficerski GK PWŚ, z 17.07.1924r., k. 35-36.

${ }^{17}$ E. Długajczyk, op. cit. s. 45.

${ }^{18}$ APK, PWŚ, sygn. 25, Sprawozdanie z lustracji..., k. 182.

${ }^{19}$ S. Kozdrowski, Wyszkolenie policyjne w II Rzeczypospolitej, Kraków 2006, s. 427-429.
} 
służby śledczej; znajomość osób podejrzanych i nadzór nad nimi; sprawdzanie tożsamości przestępców (kontrola dowodów osobistych lub paszportów, opis cech zewnętrznych, zdjęcia, daktyloskopia); badania oskarżonych i świadków; rewizje; aresztowania; poszukiwania; pościgi; konfidenci; obserwacje; inwigilacje ogólne i indywidualne ${ }^{20}$.

\section{SŁUŻBA ŚLEDCZA}

W ramach PP obok policji politycznej niezależnie działała służba śledcza kryminalna. Ich zespolenie nastąpiło w 1928 r. Podlegające Urzędowi Śledczemu wydziały śledcze do 1928 r. zajmowały się wykrywaniem przestępstw o charakterze kryminalnym. Po 1928 r. dokonano ich reorganizacji. Ekspozytury Policji Politycznej, działające przy starostwach lub dyrekcjach policji, włączono w struktury wydziałów śledczych. Podzielono je na dwa piony: kryminalny i polityczny. Każdy z nich dzielił się na brygady, na których czele stali kierownicy brygad w stopniu od aspiranta do starszego przodownika. Kierownicy brygad służbowo podlegali naczelnikowi Urzędu Śledczego. W zakresie informacji o ruchach politycznych podlegali oni starostom i dyrektorom policji. Brygady wykonujące zadania związane z przeciwdziałaniem nielegalnej działalności organizacji niemieckich oraz ruchu komunistycznego podlegały naczelnikowi Wydziału Bezpieczeństwa. Dla przykładu kierownik brygady nr VII, zajmującej się zwalczaniem szpiegostwa, dywersji i sabotażu, podlegał w pierwszej kolejności szefowi Oddziału II SG WP, następnie naczelnikowi Wydziału Bezpieczeństwa, a na końcu naczelnikowi Urzędu Śledczego. Podoficerowie Urzędu Śledczego sporządzali raporty dla Wydziału Bezpieczeństwa oraz Ministerstwa Spraw Wewnętrznych w zakresie interesujących je zagadnień. Urząd Śledczy nadzorował pracę śledczą miejskich i powiatowych komend oraz gromadził zbierane przez nie informacje. Naczelnik i jego zastępca przeprowadzali kontrole placówek terenowych. Mogli również wydać decyzję o przeniesieniu funkcjonariuszy do innych jednostek, jeżeli wymagała tego sytuacja ${ }^{21}$.

\section{METODY PRACY OPERACYJNEJ POLICJI POLITYCZNEJ}

Władze administracji państwowej nadały funkcjonariuszom policji uprawnienia, które umożliwiały im realizację przypisanych ustawowo zadań związanych z utrzymaniem ładu, porządku i bezpieczeństwa publicznego. Policjanci mogli dokonywać aresztowań i zatrzymań, przeprowadzać rewizje i przeszukania, kontrolować korespondencję prywatną i urzędową, prowadzić wywiad konfidencjonalny, inwigilację indywidualną oraz zbiorową ${ }^{22} .5$ lutego 1929 r. komendant główny PP wydał Instrukcję służby śledczej, w której zawarto rozbudowany katalog czynności operacyjno-rozpoznawczych. Szczególnie istotne w zakresie pracy operacyjnej

\footnotetext{
${ }^{20}$ APK, Urząd Wojewódzki Śląski, sygn. 107, Program 12-miesięcznego szkolenia funkcjonariuszy Policji Politycznej, z 1924r., k. 232.

${ }^{21}$ Instytut Pamięci Narodowej, Oddział w Katowicach (dalej: IPN Ka), sygn. 031/31 cz. 1, Urząd Śledczy, k. $167-168$.

22 Z. Siemak, Specyfika stużby policyjnej II Rzeczypospolitej, [w:] Bezpieczeństwo wewnętrzne Drugiej Rzeczypospolitej, red. A. Pepłoński, A. Szymanowicz, A. Gołębiowski, Wrocław 2010, s. 179-180.
} 
policji było przeciwdziałanie i zwalczanie szpiegostwa, dywersji, sabotażu, przestępczości zagrażającej ustrojowi państwa, jego suwerenności i integralności terytorialnej, nienaruszalności granic, a ponadto przestępczości o charakterze gospodarczym i kryminalnym.

Prowadzone przez PP czynności operacyjno-rozpoznawcze nie były objęte kontrolą wymiaru sprawiedliwości ${ }^{23}$. Często stosowaną przez służbę śledczą polityczną metodą był wywiad konfidencjonalny. Informacje pozyskiwane $\mathrm{w}$ ten sposób były włączane do gromadzonego w danej sprawie materiału dowodowego, a nawet stanowiły jego istotną część. Podstawowe cele wywiadu konfidencjonalnego określono w instrukcji, w której czytamy, że: „[...]policja polityczna prowadzi w dziedzinie życia publicznego obserwację wszystkich ważniejszych faktów, wydarzeń i zjawisk [...]"24. W zakresie jej zainteresowań były informacje dotyczące działalności organizacji czy stowarzyszeń. Pozyskiwano je w sposób bezpośredni od konfidentów, będących członkami rozpracowywanej organizacji, oraz w sposób pośredni od informatorów, którzy zbierali potrzebne dane, przeważnie utrzymując kontakty towarzyskie z działaczami czy dziennikarzami. Za najbardziej wartościowe uznawano informacje otrzymywane od osób zaangażowanych w działalność rozpracowywanej organizacji, zwłaszcza pełniących funkcje kierownicze. Dobrą praktyką miało być podejmowanie współpracy w danej sprawie z kilkoma konfidentami z jednej organizacji, aby mieć kontrolę nad ich pracą i ustrzec się przed celową dezinformacją ${ }^{25}$. Często jednak proces analizy dokumentów i oceny ich wiarygodności pozostawiał wiele do życzenia.

Przy typowaniu osoby do współpracy konieczne było uwzględnienie motywacji, a także typu organizacji, do której należała. W instrukcji zaznaczono, że ważne w tym względzie było indywidualne podejście do każdego kandydata. W przypadku organizacji legalnych starano się pozyskać do współpracy osoby dobrze zorientowane w ich wewnętrznym funkcjonowaniu, aktywne, mające dostęp do kluczowych informacji. Szczególnie zwracano uwagę na te, posiadające pewne cechy charakteru czy skłonności, dzięki którym ich przydatność informacyjna mogła być większa. W organizacjach nielegalnych, zwłaszcza komunistycznych, pozyskanie współpracownika oceniano jako trudne. Wynikało to $\mathrm{z}$ dużego przywiązania członków ruchu komunistycznego do ideologii, połączonego z wrogim stosunkiem do władz Drugiej Rzeczypospolitej. Ponadto obawiali się oni, że w przypadku ujawnienia ich współpracy z policją będą nazywani konfidentami, a także spotkają ich restrykcje ze strony partii. Innym rozwiązaniem było wprowadzenie przez policję do organizacji zaufanej osoby. Zaczynała ona od najniższego szczebla w hierarchii. Jednak dzięki zapewnionemu bytowi i ochronie przed odpowiedzialnością karną mogła swobodnie działać i dość szybko awansować ${ }^{26}$.

Policja polityczna stosowała różne metody werbunkowe w zależności od sytuacji. W celu nawiązania współpracy wykorzystywano m.in. groźbę pozbawienia pracy lub zwolnienie

\footnotetext{
${ }^{23}$ B. Sprengel, Praca operacyjna Policji, Toruń 2018, s. 54-55.

${ }^{24}$ IPN Ka 0103/ 42, Organizacja służby śledczej, k. 446.

${ }^{25}$ Ibidem, k. 447.

${ }^{26}$ Ibidem, k. 448.
} 
z pracy (nacisk ekonomiczny); groźbę pozbawienia wolności lub pozbawienie wolności; przekonywanie o szkodliwej dla państwa działalności danej partii politycznej czy organizacji; pozyskiwanie zdeklarowanych przeciwników ugrupowań politycznych czy stowarzyszeń; pozbawienie możliwości nauki lub studiowania; wynagradzanie (korzyść finansowa lub intratne stanowisko pracy); różne formy szantażu; przymus psychiczny i fizyczny ${ }^{27}$.

Bardzo ważne było konspirowanie werbunków, ponieważ od tego zależała późniejsza przydatność konfidentów. Stosowano różne metody konspiracyjne. Jedną z nich było umożliwienie zatrzymanemu (konfidentowi) ucieczki podczas konwoju do zakładu karnego. Pozorowano przy tym użycie broni. Innym sposobem było zwolnienie $\mathrm{z}$ aresztu kilku osób, w tym konfidenta, co uzasadniano brakiem dowodów winy, nawet jeśli takie były i kwalifikowały sprawę do sądu. Czasem zwolnienie nie było możliwe. Ustalano wówczas z prokuratorem i sędzią niski wymiar kary. Konfident po zwolnieniu z aresztu kontynuował współpracę. Materiały od konfidentów, których oceniano jako szczególnie przydatnych w pracy operacyjnej, odbierano w mieszkaniach konspiracyjnych. Z innymi spotykano się w ustalonych miejscach. Według obowiązujących zasad tożsamość konfidenta miała być znana wyłącznie funkcjonariuszowi, z którym miał on bezpośredni kontakt, oraz jego zwierzchnikowi. W praktyce policyjnej personalia konfidentów znane były jednak kilku pracownikom, co wynikało z kwestii organizacyjnych, chociażby urlopów, podczas których przekazywano dane kolegom z jednostki. W celu zakonspirowania prawdziwych danych osobowych konfidentom nadawano pseudonim ${ }^{28}$.

$\mathrm{Na}$ początku współpracy określano zasady i wyznaczano zadania. Od konfidenta oczekiwano należytego wykonywania obowiązków zleconych przez PP. Był on zobligowany do udzielania informacji o nielegalnej działalności organizacji, której był członkiem. Zwracano uwagę na poufność i wiarygodność przekazywanych wiadomości. Duże znaczenie w pracy operacyjnej PP miało rozpoznanie działań stowarzyszenia i jego planów, w kontekście bezpieczeństwa państwa. Funkcjonariusz policji politycznej musiał posiadać umiejętność analizy przekazywanych informacji pod kątem ich wiarygodności i rzetelności. Istotny w tym względzie był czas, w którym wiadomość od konfidenta docierała do policji. Zbyt późne dostarczenie informacji mogło mieć negatywne konsekwencje w postaci opóźnionego działania PP. Konfident zobowiązany był do zachowania dyskrecji. Do poufności we współpracy przykładano wysoką wagę. Za dobrego konfidenta uznawano osobę, która nie zwracała na siebie uwagi, nie łamała prawa, nie upijała się, nie pożyczała pieniędzy, nie żyła ponad stan. Dodatkowym atutem była umiejętność nawiązywania kontaktów towarzyskich z osobami, które mogły być źródłem interesujących policję informacji. Konfident wykonując swoją pracę miał działać ostrożnie. O dekonspiracji musiał niezwłocznie powiadomić jednostkę PP. Za udzielane informacje był wynagradzany finansowo ${ }^{29}$.

\footnotetext{
${ }^{27}$ Ibidem, k. 449.

${ }^{28}$ Ibidem, k. 450-451.

${ }^{29}$ Ibidem, k. 452
} 
Celem sieci konfidencjonalnej prowadzonej przez policję polityczną było rozpracowanie struktur organizacyjnych oraz składów osobowych partii politycznych i stowarzyszeń, zwłaszcza nielegalnych. Następnym krokiem była likwidacja ogniw organizacji oraz zatrzymanie ich działaczy. Niektórym konfidentom zlecano zadania mające na celu doprowadzenie do wewnętrznej destabilizacji. Osoby te były mocno zaangażowane w prace organizacji czy partii. Na początku starały się zdobyć zaufanie innych członków, po czym wykorzystując umiejętności manipulacyjne zakłócały jej funkcjonowanie ${ }^{30}$.

Ważnym elementem rozpoznania $w$ sprawach bezpieczeństwa publicznego była współpraca policji z informatorami. Prowadzili oni poufny wywiad i stanowili ,przedłużone ramię policji sięgające i docierające do takich miejsc zagrożonych, które dla oka i ucha policjantów są ukryte i niedostępne". Dlatego też często rekrutowano informatorów ze środowisk przestępczych lub powiązanych ze światem przestępczym. Motywacje do podjęcia współpracy z policją były różne, np.: „[...] chęć osiągnięcia korzyści materialnej, zazdrość, nienawiść, chęć zemsty, a nierzadko również [...] pobudki szlachetne, jak dobro państwa i ogółu obywateli, wgląd na interes publiczny i bezpieczeństwo, uczucie wdzięczności dla któregoś z policjantów za wyświadczoną przysługę itp." ${ }^{\text {31 }}$. Przed podjęciem ostatecznej decyzji o nawiązaniu współpracy z kandydatem na informatora funkcjonariusze policji politycznej starali się określić, z jakich pobudek działał. Potrzebne dane ustalano drogą poufnego wywiadu. Ponadto istotna była właściwa ocena deklarowanych przez kandydata możliwości dostarczania wiadomości ze źródeł, które wskazał. Policjantom zalecano, by wywiad prowadzili w sposób dyskretny, nie wzbudzający zainteresowania osób postronnych. Procedurę tę stosowano w celu potwierdzenia wiarygodności informatora, wstępnego oszacowania wartości źródła, a także ochrony policji przed zagrożeniem wynikającym z chęci celowego wprowadzenia jej w błąd. Następnie wyznaczano dalsze kierunki postępowania. Jeżeli z wcześniejszych ustaleń wynikało, że informator zdecydował się na współpracę z policją ze względu na odczuwane negatywne emocje, takie jak np. gniew, nienawiść czy zazdrość, zachowywano dystans. Wówczas przekazywane informacje najczęściej były nieprawdziwe lub wyolbrzymione. W sytuacji, gdy informator żądał zapłaty za przekazywane wiadomości, zachowywano szczególną ostrożność. W dokumencie czytamy: „[...] stoi [on -MS] niżej od przestępcy. Brak mu bowiem ostatniej szlachetnej właściwości, która u przestępcy zazwyczaj jeszcze została, tj. wierność wobec towarzyszy”. Pożądaną cechą u informatora była inteligencja, która pozwalała lepiej wykonywać mu powierzone zadania. Inteligentny informator potrafił właściwie opisać wydarzenia, zapamiętać i odtworzyć rozmowy nie wypaczając ich sensu. Potrafił zrozumieć zaistniałą sytuację i ją wytłumaczyć. Czasem nawet dawał rady, w jaki sposób daną informację można wykorzystać i zdobyć materiały dowodowe ${ }^{32}$.

\footnotetext{
${ }^{30}$ Ibidem, k. 453.

${ }^{31}$ APK, PWŚ, sygn. 8, Rozkaz nr 1611 GK PWŚ w Katowicach, z 30.04.1937r., k. 90.

${ }^{32}$ Ibidem, k. 91.
} 
Współpraca $\mathrm{z}$ informatorem opierała się na kilku zasadach: zapewnienia poczucia bezpieczeństwa $\mathrm{i}$ ochrony przed ujawieniem jego kontaktów $\mathrm{z}$ policją; obustronnego przestrzegania ustaleń; dokładnego instruktażu w zakresie właściwego sposobu postępowania, zachowania dyskrecji i ostrożności w prowadzonych działaniach (w tym celu informatorowi nadawano pseudonim i ustalano sposoby kontaktowania się z nim); niezwłocznego zerwania współpracy i pociągnięcia do odpowiedzialności karnej w przypadku umyślnego podawania przez informatora nieprawdziwych danych w celu utrudnienia prowadzonego dochodzenia lub wyłudzenia zapłaty; nie powoływania informatora na świadka podczas rozprawy sądowej ${ }^{33}$.

Niedozwolone były spotkania $\mathrm{z}$ informatorem na posterunkach, w komisariatach, mieszkaniu informatora. Zalecano wybieranie w tym celu miejsc odosobnionych, w których natknięcie się na znajomych było mało prawdopodobne. Według obowiązujących procedur miejsce i czas spotkań należało często zmieniać. W razie przypadkowego spotkania kogoś znajomego policjant i informator mieli zachowywać się jak obcy dla siebie ludzie. Kontakty $\mathrm{z}$ informatorem utrzymywał funkcjonariusz, który dokonał werbunku, jego przełożony lub wyznaczony przez niego zaufany policjant. Po zakończeniu każdego spotkania sporządzano meldunek. Opracowany dokument oddawano przełożonemu, który po zapoznaniu się z nim wydawał dalsze dyspozycje w zakresie wykorzystania otrzymanych wiadomości oraz sprawdzenia ich wiarygodności ${ }^{34}$. Informator podlegał stałej kontroli policyjnej, zwłaszcza jeśli podejrzewano, że udziela on nieprawdziwych informacji lub spotyka się z osobą podejrzaną. Ewentualne dowody świadczące o winie informatora zdobywano podczas poufnej obserwacji. Policja polityczna, uzyskując wiadomości dotyczące jednej sprawy od kilku informatorów, była w stanie zidentyfikować i wykluczyć nierzetelnego współpracownika ${ }^{35}$.

Istotną metodą wykorzystywaną przez policję polityczną $\mathrm{w}$ pracy operacyjnej była inwigilacja. Była ona podstawową formą kontroli życia politycznego, społecznego i kulturalnego ${ }^{36}$. Śledzenie nielegalnych jego przejawów miało na celu ujawnienie czynów przestępczych o charakterze antypaństwowym oraz działań zagrażających bezpieczeństwu wewnętrznemu. Czynności operacyjno-rozpoznawcze prowadzono w szerokim zakresie, również prewencyjnie. Po zamachu majowym w większym stopniu wykorzystywano je do inwigilowania i zwalczania opozycji politycznej. Działania te dotyczyły jednak różnych środowisk. Wykorzystywano poufną inwigilację indywidualną i zbiorową. Pierwsza z wymienionych dotyczyła zwłaszcza aktywnych działaczy społeczno-politycznych. Poufną inwigilacją zbiorową objęto działające w Drugiej Rzeczypospolitej partie polityczne, związki zawodowe, organizacje i stowarzyszenia, szczególnie obcych państw. Prowadzona przez

\footnotetext{
${ }^{33}$ Ibidem, k. 91-92.

${ }^{34}$ Ibidem, k. 93.

${ }^{35}$ Ibidem, k. 93-94.

${ }^{36}$ B. Sprengel, Praca operacyjna ..., s. 57.
} 
policję polityczną inwigilacja miała dostarczyć całego spektrum informacji o ich organizacji, funkcjonowaniu i zamiarach względem państwa polskiego ${ }^{37}$.

Inwigilację prowadzono również względem legalnie działających partii politycznych i organizacji, zwłaszcza jeśli istniało ryzyko przeniknięcia do ich struktur osób rozpowszechniających szkodliwą dla państwa ideologię. Śledzenie ich działalności nasiliło się po 1926 r. Od policjantów zaangażowanych $\mathrm{w}$ realizację tego typu zadań oczekiwano dokładności i sumienności. Cząstkowe wyniki pracy operacyjnej poszczególnych funkcjonariuszy składały się bowiem na szerszą analizę zagrożeń bezpieczeństwa wewnętrznego, co było kluczowe dla tworzenia dalszej strategii działania $^{38}$.

Do podejmowanych przez policję polityczną czynności operacyjnych można zaliczyć dozór policyjny. W art. 5 § 1 Rozporzadzenia Prezydenta Rzeczypospolitej z dnia 24 października 1934 r. o niektórych przestępstwach przeciwko bezpieczeństwu Państwa czytamy: „W razie skazania za przestępstwo popełnione umyślnie na karę ponad roku więzienia, sąd zarządza, jako środek zabezpieczający rozciągnięcie nad skazanym dozoru policyjnego na czas od roku do lat 5"39. Obejmowano nim osoby, które popełniły przestępstwo o charakterze antypaństwowym lub tzw. przestępstwo pospolite. Decyzje w tych sprawach wydawały władze administracyjne. Dozór w terenie sprawowali funkcjonariusze komisariatów i posterunków. Do innych czynności operacyjnych można zaliczyć kontrolę korespondencji i przesyłek pocztowych oraz mieszkań osób, które wyszły na wolność po odbyciu kary za prowadzenie działalności antypaństwowej ${ }^{40}$.

Od policjantów wymagano dobrej znajomości środowiska lokalnego. Na wsiach, gdzie ruch ludności był mały, po pewnym czasie możliwe było poznanie obywateli. Inaczej wyglądała sytuacja w miastach i dużych ośrodkach przemysłowych. Znaczny przepływ ludności uniemożliwiał poznanie ludzi oraz ułatwiał przestępcom ukrycie się, co wymagało od policjantów większego wysiłku włożonego w ich schwytanie. W miastach zarządzano obserwację w hotelach, restauracjach i na dworcach kolejowych. Obserwacją objęte były również zakłady przemysłowe. Dotyczyło to zwłaszcza firm zatrudniających wielu pracowników sezonowych oraz o dużej rotacji kadr. Szczególnie koncentrowano się na obserwacji zakładów przemysłu militarnego, kolei państwowych, zakładów użyteczności publicznej. Nawiązywano współpracę z zarządami spółek, biurami pośrednictwa pracy i biurami meldunkowymi ${ }^{41}$.

Zalecano, by obserwację prowadzić za pośrednictwem zaufanych osób: sąsiadów, dozorców, właścicieli domów, urzędników, kelnerów oraz konfidentów. Policja sama prowadziła obserwację bezpośrednią osób i mieszkań. Podczas prowadzonych czynności pozyskiwano materiały dowodowe. Rezultaty obserwacji, również negatywne, funkcjonariusze

\footnotetext{
${ }^{37}$ APK, PWŚ, sygn. 24, KG PP, Instrukcja o sposobie prowadzenia służby śledczej w zakresie resortu wydziału IV-D przez Powiatowe Komendy PP, z br., k. 20.

${ }^{38}$ Ibidem, k. 21-22.

39 Rozporządzenie Prezydenta Rzeczypospolitej z dnia 24 października 1934r. o niektórych przestępstwach przeciwko bezpieczeństwu Państwa, D. U. RP, nr 94, poz. 851.

${ }^{40}$ B. Sprengel, Aspekty procesowe ścigania szpiegostwa w przedwojennej Polsce, [w:] Kontrwywiad II RP (1914) 1918-1945 (1948), t. II, red. Z. Nawrocki, Warszawa 2014, s. 76-77.

${ }^{41}$ APK, PWŚ, sygn. 19, Okólnik nr 124 GK PWŚ w Katowicach, z 20.02.1927r., k. 298.
} 
zapisywali w notatnikach służbowych, a następnie zamieszczali na kartach kontroli podejrzanych. Po zgromadzeniu materiału obciążającego zarządzano obławę. Przeprowadzano ją w sposób poufny, w porozumieniu z władzami administracyjnymi, Urzędem Śledczym i kierownictwem policji. Obławy zarządzano w określonym celu, np. schwytania znanego przestępcy, jak też w związku z realizacją ogólnego celu, czyli zapewnienia porządku i bezpieczeństwa publicznego. Wymagało to przeprowadzenia dodatkowych czynności, obserwacji osób podejrzanych i dokładnego rozpoznania na terenie danej miejscowości, które mogły zakończyć się schwytaniem sprawcy przestępstwa. Obławy przeprowadzano zgodnie z określonym planem lub zarządzano doraźnie, bezpośrednio po dokonaniu przestępstwa. W drugim przypadku jednostki policyjne były niezwłocznie wzywane do pościgu za sprawcą. Od policjantów oczekiwano szybkości i gotowości do działania. Kierownik obławy sporządzał szczegółowy plan działania. Wyniki komendant oddziału zamieszczał w raporcie składanym kierownikowi ${ }^{42}$. Obława była jedną z podstawowych metod działania w przypadku napadów rabunkowych na drogach. $\mathrm{Na}$ dworcach organizowano obławy na kieszonkowców. Niektóre z nich przeprowadzano w celach propagandowych, ponieważ odbiór społeczny działań zmierzających do ograniczenia pospolitej przestępczości kryminalnej i schwytania ukrywających się przestępców był bardzo dobry ${ }^{43}$.

W Policji Państwowej (w tym służbie śledczej politycznej) obowiązywały pewne zasady, które wyznaczały ramy jej funkcjonowania. Do najważniejszych można zaliczyć: wyłączność, jednolitość i apolityczność. Pierwsza z nich określała istotną rolę, jaką policja miała odgrywać w systemie bezpieczeństwa wewnętrznego Drugiej Rzeczypospolitej. Działalność innych, wyspecjalizowanych organów o podobnym zakresie zadań prowadziła czasem do nieporozumień i sporów kompetencyjnych ${ }^{44}$. Zasada jednolitości oznaczała obowiązywanie tych samych przepisów, określających prawa i obowiązki, względem wszystkich funkcjonariuszy. Zasada apolityczności znajdowała odzwierciedlenie w zakazie przynależności policjantów do partii politycznych i stowarzyszeń. W rozkazach KG PP nakazywano apolityczność i bezstronność policji. Wobec funkcjonariuszy łamiących tę zasadę stosowano kary, z pozbawieniem posady włącznie $^{45}$. Należy jednak zauważyć, że zasada ta nie była do końca respektowana przez władze państwowe, które często wykorzystywały służby policyjne do prowadzenia inwigilacji legalnego i nielegalnego życia społeczno-politycznego w całym państwie. Od połowy 1926 r. działania te przybrały na sile i były prowadzone w szerszym zakresie, co nie zawsze wynikało ze szczególnych względów zapewnienia bezpieczeństwa publicznego ${ }^{46}$. Nie zmienia to jednak ogólnej pozytywnej

\footnotetext{
${ }^{42}$ Ibidem, k. 300-302.

${ }^{43}$ B. Sprengel, Praca operacyjna..., s. 58-59.

${ }^{44}$ Szerzej vide: H. Ćwięk, W tajnej stużbie II Rzeczpospolitej. Wywiad polski wobec Niemiec w latach 1918-1939, Częstochowa 2009, passim.

${ }^{45}$ P. Majer, Bezpieczeństwo wewnętrzne Polski w rozwoju dziejowym od X wieku do końca Polski Ludowej, Szczytno 2012, s. 164-165.

${ }^{46}$ Bezpieczeństwo wewnętrzne Drugiej Rzeczypospolitej, red. A. Pepłoński, A. Szymanowicz, A. Gołębiowski, Wrocław 2010, s. 8.
} 
oceny działalności policji politycznej, która wykonywała swoje zadania - na miarę swoich możliwości kadrowo-finansowych - zgodnie z oczekiwaniami władz ${ }^{47}$.

\section{Podsumowanie}

Policja polityczna odgrywała istotną rolę w systemie bezpieczeństwa wewnętrznego Drugiej Rzeczypospolitej. Mimo przeprowadzonych zmian organizacyjnych w jej strukturach cele nie zostały zmienione. Realizowano działania o charakterze operacyjno-rozpoznawczym, które obejmowały przeciwdziałanie i zwalczanie szpiegostwa, dywersji, sabotażu, przestępczości zagrażającej ustrojowi państwa, jego suwerenności i integralności terytorialnej, nienaruszalności granic, a ponadto przestępczości o charakterze gospodarczym i kryminalnym. Formacja ta wykorzystywała wszystkie możliwe metody działań operacyjnych.

$\mathrm{Na}$ uwagę zasługuje model współpracy z informatorami i konfidentami, który przynosił określone korzyści. W organizacjach nielegalnych, zwłaszcza komunistycznych, pozyskiwanie współpracowników nie było łatwe. Wynikało to z dużego przywiązania członków ruchu komunistycznego do ideologii, połączonego $\mathrm{z}$ wrogim stosunkiem do władz Drugiej Rzeczypospolitej. Ponadto obawiali się oni, że w przypadku ujawnienia ich współpracy z policją, będą nazywani konfidentami, a także spotkają ich restrykcje ze strony partii.

Policja polityczna stosowała różne metody werbunkowe w zależności od sytuacji. W celu nawiązania współpracy wykorzystywano m.in. groźbę pozbawienia pracy lub zwolnienie z niej, co było formą nacisku ekonomicznego; pozbawianie wolności lub groźbę jej utraty; przekonywanie o szkodliwej dla państwa działalności danej partii politycznej czy organizacji; pozyskiwanie zdeklarowanych przeciwników ugrupowań politycznych czy stowarzyszeń; pozbawienie możliwości nauki lub studiowania; wynagradzanie jako forma korzyści finansowej lub intratne stanowisko pracy; różne formy szantażu; przymus psychiczny i fizyczny etc.

Należy zwrócić uwagę, że celem sieci konfidencyjnej prowadzonej przez policję polityczną było rozpracowanie struktur organizacyjnych oraz składów osobowych partii politycznych i stowarzyszeń, zwłaszcza nielegalnych. Następnym krokiem była likwidacja ogniw organizacji oraz zatrzymanie ich działaczy.

$\mathrm{Na}$ podkreślenie zasługuje inwigilacja, jako jedna $\mathrm{z}$ metod wykorzystywanych przez policję polityczną w pracy operacyjnej. Była ona podstawową formą kontroli życia politycznego, społecznego i kulturalnego. Śledzenie nielegalnych jego przejawów miało na celu ujawnienie czynów przestępczych o charakterze antypaństwowym oraz działań zagrażających bezpieczeństwu wewnętrznemu. Czynności operacyjno-rozpoznawcze prowadzono w szerokim zakresie, również prewencyjnie. Po zamachu majowym w 1926 r. w większym stopniu wykorzystywano je do inwigilowania i zwalczania opozycji politycznej.

\footnotetext{
${ }^{47}$ K. Halicki, Policja Polityczna w województwie..., s. 428.
} 
Policja polityczna posiadała stosunkowo dobre rozpoznanie środowiska przestępczego. Osiągała zadowalające rezultaty w wykrywaniu przestępstw o charakterze antypaństwowym, wspomagając $\mathrm{w}$ walce $\mathrm{z}$ zagrożeniami inne organy bezpieczeństwa.

\section{BIBLIOGRAFIA}

Ćwięk Henryk. 2009. W tajnej służbie II Rzeczpospolitej. Wywiad polski wobec Niemiec w latach 1918-1939. Częstochowa: Wydawnictwo Akademii im. Jana Długosza w Częstochowie.

Długajczyk Edward. 2010. „Agendy polityczno-śledcze Policji Województwa Śląskiego w latach 1922-1939”. Szkice Archiwalno-Historyczne, nr 6: 35-57.

Halicki Krzysztof. 2015. Policja Polityczna w województwie pomorskim w latach 1920-1939. Łódź: Księży Młyn Dom Wydawniczy.

Kozdrowski Stanisław. 2006. Wyszkolenie policyjne w II Rzeczypospolitej. Kraków: European Association for Security.

Majer Piotr. 2012. Bezpieczeństwo wewnętrzne Polski w rozwoju dziejowym od X wieku do końca Polski Ludowej. Szczytno: Wydawnictwo Wyższej Szkoły Policji w Szczytnie.

Mącior-Majka Beata. 2014. Policja polityczna: zadania i ich realizacja w latach 1919-1926. W: Kontrwywiad II RP (1914) 1918-1945 (1948), t. II, 44-48. Warszawa: Agencja Bezpieczeństwa Wewnętrznego, Centralny Ośrodek Szkolenia w Emowie.

Mikitin Janusz. 2007. Szkolnictwo policyjne w województwie śląskim w okresie międzywojennym (rozprawa doktorska). Katowice: Uniwersytet Śląski, Wydział Nauk Społecznych, Instytut Historii.

Misiuk Andrzej. 1996. Policja Państwowa 1919-1939: powstanie, organizacja, kierunki działania. Warszawa: Wydawnictwo Naukowe PWN.

Misiuk Andrzej. 2014. System służb specjalnych w II RP. W: Kontrwywiad II RP (1914) 19181945 (1948), t. II, 11-16. Warszawa: Agencja Bezpieczeństwa Wewnętrznego, Centralny Ośrodek Szkolenia w Emowie.

Pepłoński Andrzej, Szymanowicz Adam, Gołębiowski Artur (red.) 2010. Bezpieczeństwo wewnętrzne Drugiej Rzeczypospolitej. Wrocław: Wyższa Szkoła Oficerska Wojsk Lądowych im. generała Tadeusza Kościuszki.

Rozporządzenie Prezydenta Rzeczypospolitej z dnia 24 października 1934r. o niektórych przestępstwach przeciwko bezpieczeństwu Państwa, D. U. RP, nr 94, poz. 851.

Siemak Zbigniew. 2010. Specyfika służby policyjnej II Rzeczypospolitej. W: Bezpieczeństwo wewnętrzne Drugiej Rzeczypospolitej. Wrocław: Wyższa Szkoła Oficerska Wojsk Lądowych im. generała Tadeusza Kościuszki.

Sprengel Belesław. 2011. Policja Państwowa a organy władzy publicznej w polityce ochrony bezpieczeństwa wewnętrznego w Polsce w latach 1918-1939. Toruń: Wydawnictwo Naukowe Uniwersytetu Mikołaja Kopernika.

Sprengel Bolesław. 2018. Praca operacyjna Policji. Toruń: Wydawnictwo Naukowe Uniwersytetu Mikołaja Kopernika.

Sprengel Bolesław. 2014. Aspekty procesowe ścigania szpiegostwa w przedwojennej Polsce. W: Kontrwywiad II RP (1914) 1918-1945 (1948), t. II, 74-90. Warszawa: Agencja Bezpieczeństwa Wewnętrznego, Centralny Ośrodek Szkolenia w Emowie. 